\title{
PENINGKATAN HASIL BELAJAR MATEMATIKA TENTANG PENJUMLAHAN BILANGAN DENGAN MENGGUNAKAN METODE PERMAINAN PADA PESERTA DIDIK KELAS I SD NEGERI 12 KEPAHIANG
}

\author{
Melyati
}

\begin{abstract}
Abstrak
Tujuan penelitian ini adalah untuk meningkatkan hasil belajar siswa, membuat siswa lebih semangat dan aktif dalam mengikuti pelajaran. Metode penelitian yang digunakan adalah penelitian tindakan kelas dengan dua siklus. Setiap siklus terdiri dari dua pertemuan. Instrumen penelitian yang digunakan adalah (1) instrumen pembelajaran berupa rencana pelaksanaan pembelajaran, lembar kerja siswa dan alat peraga, (2) instrumen pengumpulan data berupa tes dan non tes yang digunakan untuk mengetahui hasil belajar siswa dengan menggunakan metode permainan. Hasil penelitian menunjukkan bahwa penerapan metode permainan yang dikembangkan dalam penelitian ini memilki pengaruh yang signifikan terhadap peningkatan hasil belajar siswa kelas I SD Negeri 12 Kepahiang. Hal ini ditunjukkan pada siklus I dan siklus II yang dikelompokkan menjadi tiga kategori, yaitu siswa tinggi, siswa sedang, dan siswa rendah. Adapun hasil belajar siswa pada siklus I dan siklus II yaitu skor rata-rat hasil belajar siswa pada kategori tinggi adalah 79.8 dan meningkat menjadi 90.5 Skor rata-rata hasil belajar siswa pada kategori sedang adalah 66.4 dan meningkat menjadi 70.8 Dan skor rata-rata hasil belajar siswa pada kategori rendah adalah 53.3 dan meningkat menjadi 60, sedangkan sikap siswa berdasarkan hasil non tes adalah siswa menjadi senang, semangat dan aktif dalam mengikuti kegiatan pembelajaran.
\end{abstract}

Kata Kunci: Permainan, Hasil Belajar Matematika.

\section{PENDAHULUAN}

Matematika merupakan salah satu bidang studi yang diajarkan di sekolah dasar.Seorang guru SD yang akan mengajarkan matematika kepada siswanya, hendaklah mengetahui dan memahami objek yang akan diajarkan, yaitu matematika. Sebagaimana tercantum dalam kurikulum matematika sekolah bahwa tujuan diberikannya matematika, antara lain agar siswa mampu menghadapi perubahan keadaan di dunia yang selalu berkembang, melalui latihan bertindak atas dasar pemikiran secara logis, rasional, kritis, cermat, jujur dan efektif. Hal ini jelas merupakan tuntutan sangat tinggi yang tidak mungkin bisa dicapai hanya melalui hapalan, latihan pengerjaan soal yang bersifat rutin, serta proses pernbelajaran biasa. Untuk menjawab tuntutan tujuan yang demikian tinggi, maka perlu dikembangkan materi serta proses pembelajarannya yang sesuai.

Berdasarkan hasil observasi yang dilakukan peneliti di SD Negeri 12 
Kepahiang ternyata siswa kelas I masih ada yang mengalami kesulitan dalam menghitung penjumlahan. Kesulitan dalam menghitung penjumlahan dipengaruhi oleh beberapa hal, yaitu dalam mengajarkan guru lebih sering menggunakan metode ceramah dan jarang menggunakan metode permainan. Sedangkan anak usia SD kelas I adalah anak yang berada pada usia 6-8 tahun. Pada usia ini anak masih berpikir pada tahap konkret artinya kelas I belum berpikir formal. Ciriciri anak pada tahap ini dapat memahami operasi logis dengan bantuan benda-benda konkret. Selain itu anak pada usia ini masih senang bermain, dan masalah lain yang dihadapi guru dalam menyajikan materi matematika adalah jumlah siswa yang banyak, situasi kelas yang kurang kondusif, menjadikan tidak semua siswa dapat memperhatikan apa yang diterangkan oleh guru secara seksama.

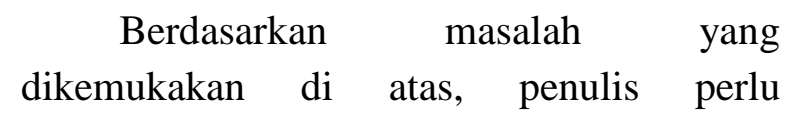
melakukan penelitian tindakan kelas untuk mengatasi masalah tersebut dengan menerapkan metode permaianan untuk meningkatkan hasil belajar siswa tentang penjumlahan bilangan. Karena metode permainan adalah suatu kegiatan yang menggembirakan yang dapat menunjang tercapainya kompetensi dasar dalam pengajaran Matematika baik aspek kognitif, afektif maupun psikomotor (dalam Rusffendi, 1998:312). Penelitian tindakan kelas merupakan penelitian yang mampu menawarkan cara dan prosedur baru untuk memperbaiki dan meningkatkan profesionalisme guru dalam proses dan hasil pembelajaran yang terjadi pada siswa. Rumusan masalah dalam penelitian ini adalah sebagai berikut: (1) Apakah penggunaan metode permainan dapat meningkatkan hasil belajar siswa dalam menjawab soal penjumlahan bilangan?

Bagaimanakah aktivitas siswa dalam pembelajaran matematika dengan menggunakan metode permainan?

\section{METODE}

Metode penelitian yang digunakan adalah penelitian tindakan kelas (PTK). Pertimbangan yang mendasari penelitian tindakan kelas ini ialah untuk memecahkan masalah pembelajaran matematika yang dihadapi sendiri oleh peneliti sehingga tidak akan mengganggu proses pembelajaran yang sedang berlangsung. Bentuk penelitian yang digunakan dalam penelitian ini adalah penelitian kelas dengan model Kemmis dan Mc Taggart. Tahap-tahap penelitian ini dimulai dengan perencanaan tindakan, peraksanaan tindakan, observasi dan penelitian ini akan dilaksanakan dalam dua siklus. Aktivitas penelitian ini melalui tahapan siklus.

Instrumen pembelajaran yang digunakan dalam penelitian ini adalah rencana pelaksanaan pembelajaran (RPP), lembar kerja siswa (LKS), dan alat peraga. Instrumen pembelajaran ini diperlukan untuk menunjang kelancaran pelaksanaan pembelajaran di dalam kelas. Rencana pelaksanaan pembelajaran (RPP) pada dasarnya adalah pedoman operasional kegiatan pembelajaran yang akan dilakukan. (Sukirman, 2006:243). Dengan demikian setiap aktivitas yang dilakukan selama proses pembelajaran selalu mengacu pada rencana yang telah-dibuat. Dalam penelitian ini peneliti membuat empat rencana pelaksanaan pembelajaran (RPP) yang digunakan untuk dua siklus.

Pengumpulan data dilakukan pada setiap pelaksanaan pembelajaran dengan 
melihat setiap aktivitas yang dilakukan oleh siswa. Data yang dikumpulkan berupa data hasil tes dan non tes. Data hasil tes dilakukan dengan memberikan tes formatif pada setiap akhir siklus untuk mengevaluasi proses pembelajaran, dan memberikan tes sub sumatif pada akhir seluruh siklus untuk mengevaluasi hasil pembelajaran dan melihat ketercapaian target yang diinginkan.

Data hasil nontes dilakukan dengan menggunakan angket, lembar observasi dan pedoman wawancara. Angket diberikan kepada siswa pada setiap akhir siklus. Jawaban angket dibuat oleh siswa berdasarkan atas apa yang telah diperoleh selama mengikuti pembelajaran matematika, dan juga perasaan siswa selama mengikuti kegiatan pembelajaran matematika. Wawancara dilakukan pada setiap akhir siklus, tidak semua siswa diwawancara karena akan membutuhkan waktu yang cukup lama, sehingga hanya beberapa siswa yang mewakili kelompok tinggi, sedang, dan kurang. Lembar observasi siswa dan guru diberikan kepada observer. Observasi dilakukan untuk mengamati aktivitas siswa selama berlangsungnya kegiatan pembelajaran.

\section{HASIL}

\section{Deskripsi Hasil Penelitian Siklus I}

Pada tahap perencanaan tindakan Siklus I, peneliti melakukan analisis kurikulum (KTSP 2006) dan buku pelajaran matematika kelas I kemudian peneliti membuat rencana pelaksanaan pembelajaran (RPP), mempersiapkan alat peraga serta LKS dan menyiapkan format lembar observasi pelaksanaan pembelajaran.

Siklus I dilaksanakan dalam dua pertemuan. Pelaksanaan tindakan pertemuan pertama aktivitas siswa diamati juga oleh peneliti. Pokok bahasan yang dibahas adalah penjumlahan bersusun pendek tanpa menyimpan. Pada pelaksanaan pertemuan pertama ini siswa dikelompokkan menjadi empat kelompok. Yang setiap kelompok terdiri dari 5 orang siswa. Dalam menyelesaikan dan mengerjakan soal, siswa dalam kelompok bekerjasama dengan temannya, tetapi masih ada siswa yang mengobrol dengan temannya sehingga yang mengerjakan tugas adalah ketua kelompoknya.

Pelaksanaan pertemuan kedua ini merupakan lanjutan dari pertemuan pertama, tetapi pada pelaksanaan kedua ini tidak ada pengelompokkan siswa. Pada pertemuan kedua ini pokok bahasan yang dibahas adalah penjumlahan bersusun pendek dengan tehnik menyimpan. Pada pertemuan kedua ini siswa tampak semangat dalam mengikuti kegiatan pembelajaran. Pada pelaksanaan siklus I pertemuan kedua ini guru (peneliti) memberikan tes formatif untuk mengetahui hasil belajar siswa. Setelah setiap siswa selesai mengadakan tes formatif, guru(peneliti) kembali memberikan lembar non tes kepada siswa berupa angket.

Hasil refleksi pembelajaran pada Siklus I antara lain sebagai berikut. Hasil refleksi pada siklus I ini ada beberapa hal yang harus diperbaiki untuk meningkatkan hasil belajar siswa. Pada siklus I siswa masih suka bercanda dengan teman sebangkunya sehingga dalam mengerjakan tugas yang diberikan kurang dapat menghasilkan hasil yang baik. Untuk itupada siklus II guru (peneliti) harus dapat mengkondisikan kelas dengan baik, sehingga diharapkan tidak ada siswa yang bercanda dalam mengikuti pelajaran. Peneliti melakukan evaluasi terhadap semua proses kegiatan pembelajaran yang telah dilakukan dan dari hasil data diatas, peneliti merefleksikan dengan melihat hasil tes dan non tes untuk mengetahui apa yang perlu dilakukan 
selanjutnya dan digunakan sebagai perbaikan untuk merencanakna siklus berikutnya.

\section{Deskripsi Hasil Penelitian Siklus II}

Pada tahap ini, peneliti membuat rencana pelaksanaan pembelajaran (RPP) tentang materi penjumlahan bersususun panjang. Dengan menggunakan alat peraga berupa kelereng, lidi dan kartu angka yang akan diterapkan pada proses kegiatan belajar mengajar, mempersiapkan LKS untuk mengevaluasi hasil belajar siswa dan menyiapkan format lembar observasi pelaksanaan pembelajaran.

Kegiatan yang dilaksanakan pada tahap ini yaitu peneliti melaksanakan kegiatan pembelajaran dengan menggunakan metode permainan dan menggunakan alat peraga berupa kelereng dan kartu angka. Pelaksanaan tindakan siklus II ini dilaksanakan dalam dua pertemuan. Pada pertemuan pertama dan pertemuan kedua membahas penjumlahan bersususun panjang antara bilangan genap dengan bilangan genap dan anatar bilangan genap dengan bilangan ganjil. Pokok bahasan yang dibahas adalah tentang penjumlahan bersususn panjang antara bilangan genap dengan bilangan genap. Pada pelaksanaan pertemuan pertama ini siswa dikelompokkan menjadi 8 kelompok.

Peneliti melakukan wawancara menjelang berakhirnya siklus, wawancara tidak dilakukan kepada semua siswa kelas I, melainkan kepada perwakilan setiap kelompok siswa yang terbagi kedalam 3 kategori.

Pokok bahasan yang dibahas adalah penjumlahan bersususn panjang antara bilangan genap dengan bilngan ganjil. Pada pelaksanaan pertemuan kedua ini guru (peneliti) tidak melakukan pengelompokkan siswa. Pelaksanaan siklus II pertemuan kedua ini guru (peneliti) memberikan tes fomatif untuk mengetahui hasil belajar siswa selama mengikuti kegiatan pembelajaran. Pada pertemuan kedua ini juga dilaksanakan tes sub sumatif.

Hasil refleksi selama pelaksanaan siklus II pertemuan pertama, seluruh anggota kelompok sudah tampak kerjasama dalam melakukan kegiatan kelompok dan dalam mengerjakan tugas kelompok, dan pada pertemuan kedua hasil belajar siswa secara individu sudah ada peningkatan, namun masih ada 1 siswa yang masih lemah dalam menyelesaikan soal tes.

\section{PEMBAHASAN}

Berdasarkan hasil yang diperoleh dari siswa setelah pelaksanaan siklus I, terjadi peningkatan hasil belajar siswa yaitu skor rata-rata hasil belajar siswa pada katergori tinggi adalah 79.8 sebelumnya skor rata-rata tes awal adalah 77.2. Skor rata-rata hasil belajar siswa pada kategori sedang adalah 69.3 sebelumnya skor rata-rata tes awal adalah 66.4 dan skor rata-rata belajar siswa pada kategori rendah adalah 53.3 sebelumnya skor rata-rata tes awal adalah 50 .

Berdasarkan hasil tes dan non tes pada pelaksanaan siklus I, hasil belajar siswa dilakukan dengan memberikan evaluasi berupa LKS yang dikerjakan secara berkelompok pada pertemuan pertama, dan tes formatif pada pertemuan kedua. Evaluasi non tes juga dilaksanakan pada pertemuan kedua kecuali pelaksanaan observasi. Pelaksanaan observasi dilakukan pada setiap pertemuan dan dilaksanakan bersamaan dengan pelaksanaan tindakan. Kegiatan observasi dilakukan dengan menggunakan lembar observasi yang telah disiapkan.

Berdasarkan hasil yang diperoleh siswa setelah pelaksanaan siklus II, terjadi peningkatan hasil belajar siswa pada kategori 
tinggi 90.5 sebelumnya skor rata-rata siklus I adalah 79.8 skor rata-rata hasil belajar siswa pada kategori sedang adalah 70.8 sebelumnya skor rata-rata siklus I adalah 69.3 dan skor rata-rata belajar siswa pada kategori rendah adalah 60 sebelumnya skor rata-rata siklus I adalah 53.3. pada pelaksanaa tes sub sumatif, hasil belajar siswa juga mengalami peningkatan. Pemberian tes sub sumatif bertujuan utuk mengetahui hasil belajar siswa selama mengikuti pembelajaran dari siklus I sampai dengan siklus II.

Berdasarkan hasil tes dan non tes pada pelaksanaan siklus II hasil belajar siswa dilakukan dengan memberikan evaluasi berupa LKS yang dikerjakan secara berkelompok pada pertemuan pertama, dan tes formatif pada pertemuan kedua, pada saat pertemuan kedua juga dilakukan tes sub sumatif. Pelaksanaan observasi dilakukan pada setiap pertemuan dan dilaksanakan bersamaan dengan pelaksanaan tindakan.

\section{SIMPULAN}

Belajar dengan penggunaan metode permainan dapat meningkatkan hasil belajar siswa dalam menjawab soal penjumlahan bilangan. Hal ini ditunjukkan pada siklus I dan siklus II, adapun hasil belajar siswa pada siklus I dan siklus II yaitu skor rata-rata hasil belajar siswa pada kategori tinggi adalah 79.8 dan meningkat menjadi 90.5 Skor rata-rata hasil belajar siswa pada kategori sedang adalah 69.3 dan meningkat menjadi 70.8. Dan skor rata-rata siswa kategori rendah adalah 53.3 dan meningkat menjadi 60 Sedangkan sikap siswa berdasarkan hasil non tes adala siswa menjadi senang, semnagat dan aktif dalam mengikuti kegiatan pembelajaran. Aktifitas siswa dalam pembelajaran mate-matika dengan menggunakan metode permainan dapat membuat siswa lebih aktif.

\section{DAFTAR PUSTAKA}

Departemen Pendidikan Nasional. 2006. Kurikulum Tingkat Satuan Pendidikan. Jakarta: Depdiknas.

Kurikulum SD Negeri 12 Kepahiang tahun Pelajaran 2011/2012.

Rusffendi, ET. (1988). Pengantar kepada Membantu Guru Mengembangkan Kompetensinya dalam Pengajaran Matematika untuk Meningkatkan CBSA. Bandung: Tarsito.

Sadiman, Arief S., dkk. 2005. Media Pendidikan. Jakarta: PT Raja Grafindo Persada.

Suwangsih, Ernan dkk. 2006. Model Pembelajaran Matematika. Bandung: PT Remaja Rosdakarya. 